\title{
An ArcGIS Geo-Morphological Approach for Snow Avalanche Zoning and Risk Estimation in the Province of Bergamo
}

\author{
Barbara Marana \\ Department of Engineering and Applied Science, University of Bergamo, Dalmine (Bergamo), Italy \\ Email: barbara.marana@unibg.it
}

How to cite this paper: Marana, B. (2017) An ArcGIS Geo-Morphological Approach for Snow Avalanche Zoning and Risk Estimation in the Province of Bergamo. Journal of Geographic Information System, 9, 8397.

https://doi.org/10.4236/jgis.2017.92006

Received: February 7, 2017

Accepted: April 25, 2017

Published: April 28, 2017

Copyright $\odot 2017$ by author and Scientific Research Publishing Inc. This work is licensed under the Creative Commons Attribution-NonCommercial International License (CC BY-NC 4.0).

http://creativecommons.org/licenses/by-nc/4.0/

\begin{abstract}
This paper describes the results of a study developed, with a GIS approach, at the University of Bergamo, about snow avalanche zoning and risk assessment in the Province of Bergamo. The adoption of a simplified estimation model, presented here, nonetheless allowed achieving results in good accordance with those provided by previous, more rigorous studies at the Province of Bergamo. A following analysis has also been performed to estimate ski lifts, urban areas, power lines, highways, railroads and roads at possible risk. This is a work in progress, since further development has already been taken into account to enrich the risk model with more parameters describing land morphology and meteorology. These results will then be used to simulate accidents and to estimate the shortest routes for rescuers. Finally, the development of a geo-app for mobile devices could become a very useful and fast tool for avalanche risk areas information.
\end{abstract}

\section{Keywords}

Avalanche Zoning, Avalanche Risk Analysis in the Province of Bergamo, GIS Analysis, Higher Risk Zones Identification

\section{Introduction}

Risk Analysis is of great importance nowadays. The always increasing human action over the environment has provided a meaningful contribution to the rising of natural dangerous events which are now more frequent than in the past.

For this reason, natural dangerous phenomena, such as earthquakes, floodings landslides and avalanches, which have always been existing in our world, in time, have been amplified in intensity, frequency and consequent destroying effect. 
Today we live in highly unstable environmental conditions which are doomed to get worse and to cause huge damages to people and things.

This paper describes the subject developed with a group of students in Building Engineering at the University of Bergamo (northern Italy), for their degree thesis. The purpose is to analyse a phenomenon which is of great interest in all the mountain regions, like the Province of Bergamo: avalanche zoning and risk [1].

It is known that avalanches are both a terrific natural phenomenon (Figure 1) and a danger for people, infrastructure and building safety. Recently, in our country, namely in the Abruzzo region, a huge snow mass detachment (probably due to a series of previous earthquakes) has buried a hotel with some guests, causing great shock and emotional involvement [3] [4].

Snow avalanches have been studied for many years all over the world, mostly in countries with mountains and snow, such as Canada, USA and many Alpine European states, such as Switzerland, France, Italy, Austria, Romania and Norway.

According to the main studies developed in different scientific fields, it is possible to find a huge variety of approaches to snow avalanche risk analysis. Scholars in geology, civil and environmental engineering and geography try to solve the problem with the aid of statistical/mathematical methods and the support of GIS tools. Actually in the field of hazards it is of primary importance to estimate models for simulation, analysis and prediction [5]-[11]. Usually, the selected numerical models are quite complex and require time for their implementation and processing.

Snow avalanches belong to the gravitationally driven natural hazards (like landslides) and their modelling isn't a simple task to be accomplished, since their behaviour is highly changing due to the difference in flow and soil interaction, weather, terrain and snowpack. For this reason, there is a significant uncertainty [12] related to the problem, which is intrinsic in data collection, analysis, assessment and decision making [13] [14].

In Switzerland, a country close to Italy and for this reason sharing almost the

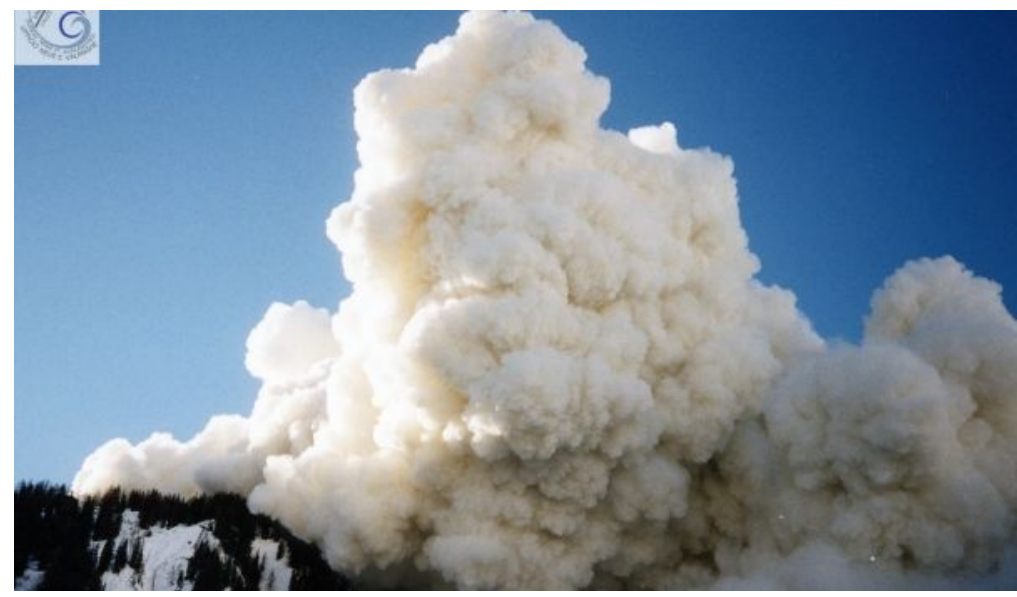

Figure 1. Amazing avalanche performance [2]. 
same problems due to climate, Alpine mountain ridges and terrain, the RAMMS (Rapid Mass Movement System) [15] module AVALANCHE has been realized to achieve an accurate prediction of mass movements runout distances, flow velocities and impact pressures in natural three-dimensional terrain. The module is widely used in Switzerland for avalanche hazard studies [16].

RAMMS is a reliable numerical simulation tool yielding runout distance, flow heights, flow velocities and impact pressure of dense flow snow avalanches, hillslope landslides and debris flows. It has been developed by a team of experts at the WSL Institute for Snow and Avalanche Research SLF [17] and the Swiss Federal Institute for Forest, Snow and Landscape Research WSL [18].

It is possible to download this software and its user manual, so as to perform analysis and simulations providing useful results. The author has planned to try this software in the next future to experiment a different approach.

As previously said, this problem has been largely analysed and studied in the world [19] [20]. Here, with a simpler approach, it has been decided to avoid the use of equations describing snow mass movement and soil interactions, but only to perform topographic map analyses with the aid of GIS tools. Geographically speaking, the selected test area is the Province of Bergamo [21], whose northern territory is characterized by mountain ridges (the Orobic Alps, with the highest peak at $3052 \mathrm{~m}$ over the sea level) and hills (Prealpi Bergamasche) (Figure 2).

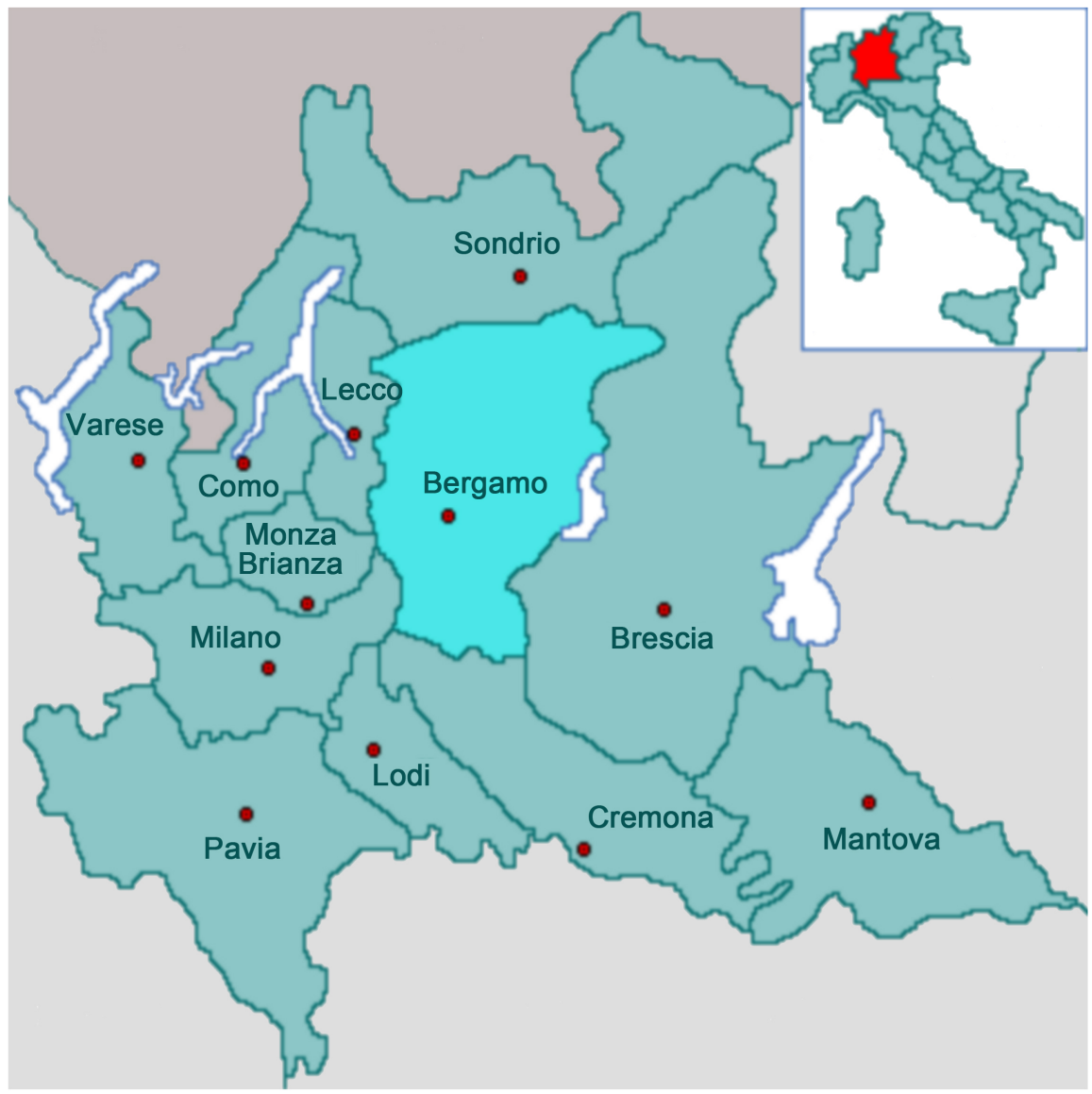

Figure 2. The province of Bergamo in northern Italy [25]. 


\section{Avalanches}

Avalanches are caused by snowy masses detaching from mountain versants and fast moving down till they are stopped by obstacles and/or weak slopes.

They can be spontaneous or derive from internal or external causes [22] [23] [24].

In the last years, the so called "white deaths" have increased both for the larger number of people practicing winter sports and because of the global average surface temperature rising [26].

\section{The Project}

A GIS analysis of the Province of Bergamo territory can be very useful to identify some fundamental causes to avalanches detachment, such as:

- terrain slope,

- land-use,

- orthometric height.

Other contributing factors have been integrated to the previous ones, being their function, like temperature (decreasing with height) and snow amount (which is increasing with height and is an inverse function of temperature).

This way, an investigation has been performed with the software package ArcGIS 10.2 by Esri [27] and its extensions 3D Analyst and Spatial Analyst.

The land data have been downloaded from the Lombardy Geoportal [28] as shapefiles, georeferenced in coordinates WGS84-UTM zone $32 \mathrm{~N}$ and at a scale of $1: 10.000$

\subsection{Data Management}

The first part of the work has been dedicated to the processing of geographical data useful for the following risk analysis.

By processing datasets of contour lines and height points, a raster DEM has been derived and, from this, the terrain slope and aspect raster layers; these data have been then classified, assigning a risk factor value (from 1 to 4 ) to each class (Table 1 and Table 2).

The Risk value, for each class, has been selected on the basis that about $97 \%$ of avalanche casualties happen where steepness is greater than $30^{\circ}$ and that the most dangerous exposition is the one to the North, because of the low temperature which makes snow more powdery and less solid.

Since Aspect identifies the downslope direction of the maximum rate of Table 1. The classified four steep risk levels.

\begin{tabular}{ccc}
\hline \multicolumn{1}{c}{ Slope } & Risk factor \\
\hline Flat or low steep & $0^{\circ}-30^{\circ}$ & 1 \\
Semi steep & $30^{\circ}-35^{\circ}$ & 2 \\
Steep & $35^{\circ}-40^{\circ}$ & 3 \\
High steep & $>40^{\circ}$ & 4 \\
\hline
\end{tabular}


Table 2. The four adopted aspect risk levels.

\begin{tabular}{ccc}
\hline & Aspect & Risk factor \\
\hline Flat areas & -1 & 0 \\
N/NE & $0-67.5^{\circ}$ & 4 \\
E & $67.5^{\circ}-112.5^{\circ}$ & 3 \\
SE & $112.5^{\circ}-157.5^{\circ}$ & 2 \\
S & $157.5^{\circ}-202.5^{\circ}$ & 2 \\
SW & $202.5^{\circ}-247.5^{\circ}$ & 1 \\
W & $247.5^{\circ}-292.5^{\circ}$ & 2 \\
$\mathrm{NW} / \mathrm{N}$ & $292.5^{\circ}-360^{\circ}$ & 3 \\
\hline
\end{tabular}

change in value from each cell to its neighbours, ArcGIS assigns a value of -1 to Flat areas.

Also the land-use shapefile has been classified (4 classes) taking into account that free and "smooth" soils (which means a not rough surface without obstacles of any kind) are more dangerous than urban areas or where vegetation is thick (these are artificial and natural obstacles to an avalanche fall) (Table 3).

This shapefile has then been converted to a raster format at the same resolution of the others, i.e. a $10 \times 10$ cell size which corresponds to $10 \mathrm{~m} \times 10 \mathrm{~m}$ on the ground.

\subsection{Orthometric Height}

In snow avalanche risk assessment, it's important to underline the meaningful relationship among orthometric height, snow precipitation (direct function) and temperature (inverse function).

For this reason, the DEM layer has been reclassified (4 classes), assigning a risk factor value increasing with height, as shown in Table 4.

Just a simple example to explain the reasoning behind this assumption: under $800 \mathrm{~m}$ it has been assigned a zero value coefficient, which means that, despite the strong avalanche influence of aspect, slope and land roughness, low height abolishes risk. For this reason, avalanche risk in flat areas isn't taken into account. The opposite happens for territories above $800 \mathrm{~m}$, where avalanche risk becomes a real problem. These zones have been assigned risk levels, related to height, of one, two and three which don't aim only to underline different height levels, but also to take into account rain downfall, air temperature, soft snow pile up and wind action [29]; as a matter of fact, snow downfall increases and wind action is stronger, due to the lack of obstacles, at higher heights.

Furthermore, also aspect, slope and land-use layers are highly influenced by height, since their risk factor increases with this parameter.

For this reason, as will be later said, the parameter, representing the contribution of height to the risk factor calculation, will be multiplied and not summed, like the others of slope, aspect and land-use; in fact, it has been gathered that height plays a prevalent role in avalanche risk. 
Table 3. The four adopted land-use risk levels.

\begin{tabular}{cc}
\hline Soil roughness & Risk factor \\
\hline Lakes, hydrographic basins, etc. & 0 \\
Forestry, wood production forestry, other forest production, etc. & 1 \\
Urban areas, industrial, commercial and artisan settlements, etc. & 2 \\
Grasslands, rock debris, exposed rocks, etc. & 3 \\
\hline
\end{tabular}

Table 4. The four adopted orthometric height risk levels.

\begin{tabular}{cc}
\hline Orthometric height $(\mathrm{m})$ & Risk factor \\
\hline $0-800$ & 0 \\
$800-1500$ & 1 \\
$1500-2000$ & 2 \\
$>2000$ & 3 \\
\hline
\end{tabular}

\section{The Risk Model}

The Risk Model has been at last developed according to the assessment provided by the previous paragraphs and therefore assuming height as the pivot factor influencing all the others; for this reason, in the model, this parameter is the only one which multiplies, while the others are added together (Equation (1)):

Avalanche Risk $=$ RiskHeight $\times[$ RiskSlope + RiskAspect + RiskLand - Use $]$

where

RiskHeight $=$ Risk by Height

RiskSlope $=$ Risk by Slope

RiskAspect $=$ Risk by Aspect

RiskLand-Use = Risk by Land-Use and specifically by soil "roughness"

Of course, this is a simplified model, if compared to more rigorous existing ones [30]-[37], to evaluate avalanches risk, but, despite the fact that it has been decided to develop it further, it works well, as demonstrated later.

Performing this equation with ArcGIS Raster Calculator tool, a final raster has been provided with a $10 \mathrm{~m} \times 10 \mathrm{~m}$ resolution, in the reference system WGS84 UTM Zone $32 \mathrm{~N}$ and showing 33 classes. This has then been reclassified in 5 classes (Table 5) according to the European 5 danger levels reference scale (Figure 3) and is illustrated in Figure 4.

\section{The Risk Model Validation}

To validate the achieved risk model, an avalanches inventory shapefile, from 1991 to 2010 in the Province of Bergamo, has been superimposed to the final raster of Figure 4.

The results of this analysis are illustrated in Figure 5.

By simply looking at Figure 5, it's possible to have an idea of the good correspondence of the achieved results to the inventory data distribution.

To get a more accurate proof of adequacy of the estimated model, it has been compared with the layer provided by the Province of Bergamo, showing snow 
Table 5. Five classes regarding the classification of the achieved results.

\begin{tabular}{cc}
\hline The original 33 risk classes & Risk \\
\hline $0-11$ & Low \\
$11-16.5$ & Moderate \\
$16.5-22$ & Considerable \\
$22-27.5$ & High \\
$27.5-33$ & Very high
\end{tabular}

\begin{tabular}{|c|c|c|c|}
\hline \multicolumn{4}{|c|}{ EUROPEAN AVALANCHE HAZARD SCALE } \\
\hline SCALE & DANGER & AVALANCHE PROBABILITY & $\begin{array}{l}\text { INDICATIONS TO SKIERS, } \\
\text { DAY-TRIPPERS AND } \\
\text { MOUNTAINEERS }\end{array}$ \\
\hline 1 & LOW & $\begin{array}{l}\text { Triggering is possible only with high } \\
\text { additional loads on a few very steep } \\
\text { extreme slopes. Only a few small } \\
\text { natural avalanches (sluffs) possible. }\end{array}$ & $\begin{array}{l}\text { Generally favourable } \\
\text { conditions for ski-trips. }\end{array}$ \\
\hline 2 & MODERATE & $\begin{array}{l}\text { Triggering is possible with high } \\
\text { additional loads, particularly on the } \\
\text { steep slopes indicated in the bulletin. } \\
\text { Large natural avalanches not likely. }\end{array}$ & $\begin{array}{l}\text { Favourable conditions for } \\
\text { ski-trips but it's required to } \\
\text { adequately consider local } \\
\text { dangerous zones. }\end{array}$ \\
\hline 3 & CONSIDERABLE & $\begin{array}{l}\text { Triggering is possible, sometimes even } \\
\text { with low additional loads. The bulletin } \\
\text { may indicate many slopes which are } \\
\text { particularly affected. In certain } \\
\text { conditions, medium and occasionally } \\
\text { large sized natural avalanches may } \\
\text { occur. }\end{array}$ & $\begin{array}{l}\text { The possibility of ski-trips is } \\
\text { limited and it's required a } \\
\text { good ability of local } \\
\text { valuation. }\end{array}$ \\
\hline 4 & HIGH & $\begin{array}{l}\text { Triggering is probable, even with low } \\
\text { additional loads on many steep slopes. } \\
\text { In some conditions, frequent medium } \\
\text { or large sized natural avalanches are } \\
\text { likely. }\end{array}$ & $\begin{array}{l}\text { The possibility of ski-trips is } \\
\text { very limited and it's } \\
\text { required an high ability of } \\
\text { local valuation. }\end{array}$ \\
\hline 5 & VERY HIGH & $\begin{array}{l}\text { Numerous large natural avalanches } \\
\text { are likely, even on moderately steep } \\
\text { terrain. }\end{array}$ & $\begin{array}{l}\text { The ski-trips are generally } \\
\text { impossible. }\end{array}$ \\
\hline
\end{tabular}

Figure 3. European danger scale with recommendations [38].

avalanche zoning (Figure 6).

Figure 7 shows two maps: the upper one represents the polygon shapefile with the red areas of Figure 6, while the lower one is the polygon shapefile extracted by our raster with ArcGIS tools.

The two shapefiles, once more, demonstrate that our model shows to work quite well.

Also an analytical comparison has been performed by calculating the risk areas in Figure 7.

The top ones, i.e. the data developed by the Province of Bergamo, have an extent of about 20,480 Ha, while the bottom ones, which show our results, of about 


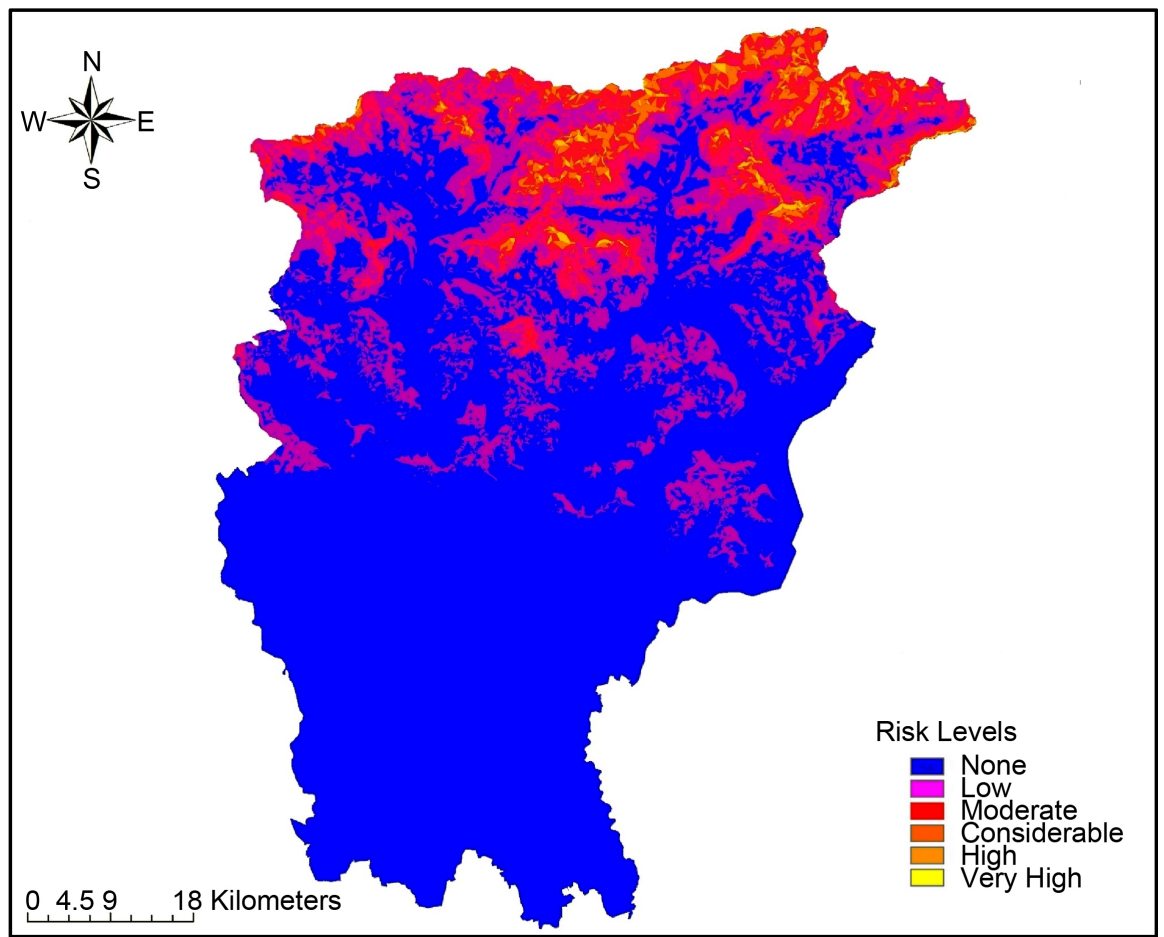

Figure 4. The developed avalanche risk map for the province of Bergamo.

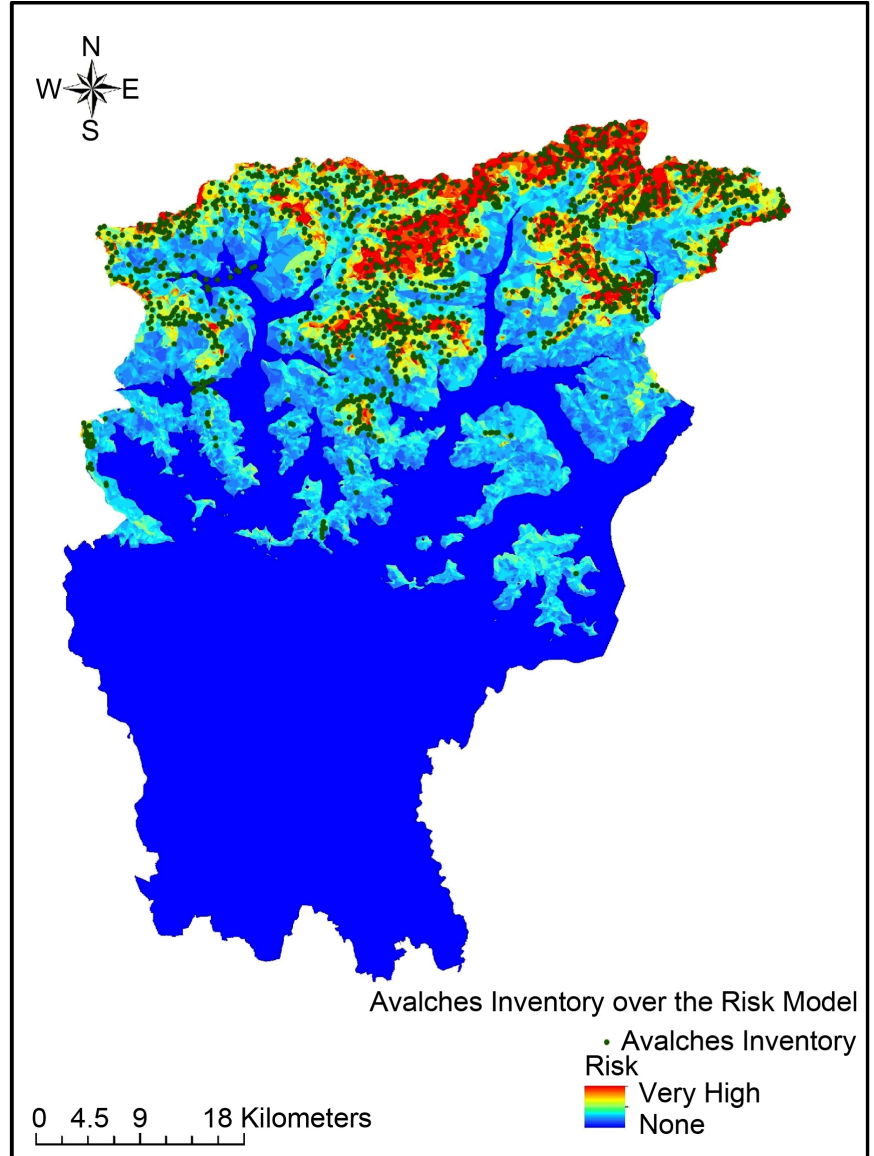

Figure 5. The Risk Model Validation showing the superimposition of the Avalanches directory point shapefile. 


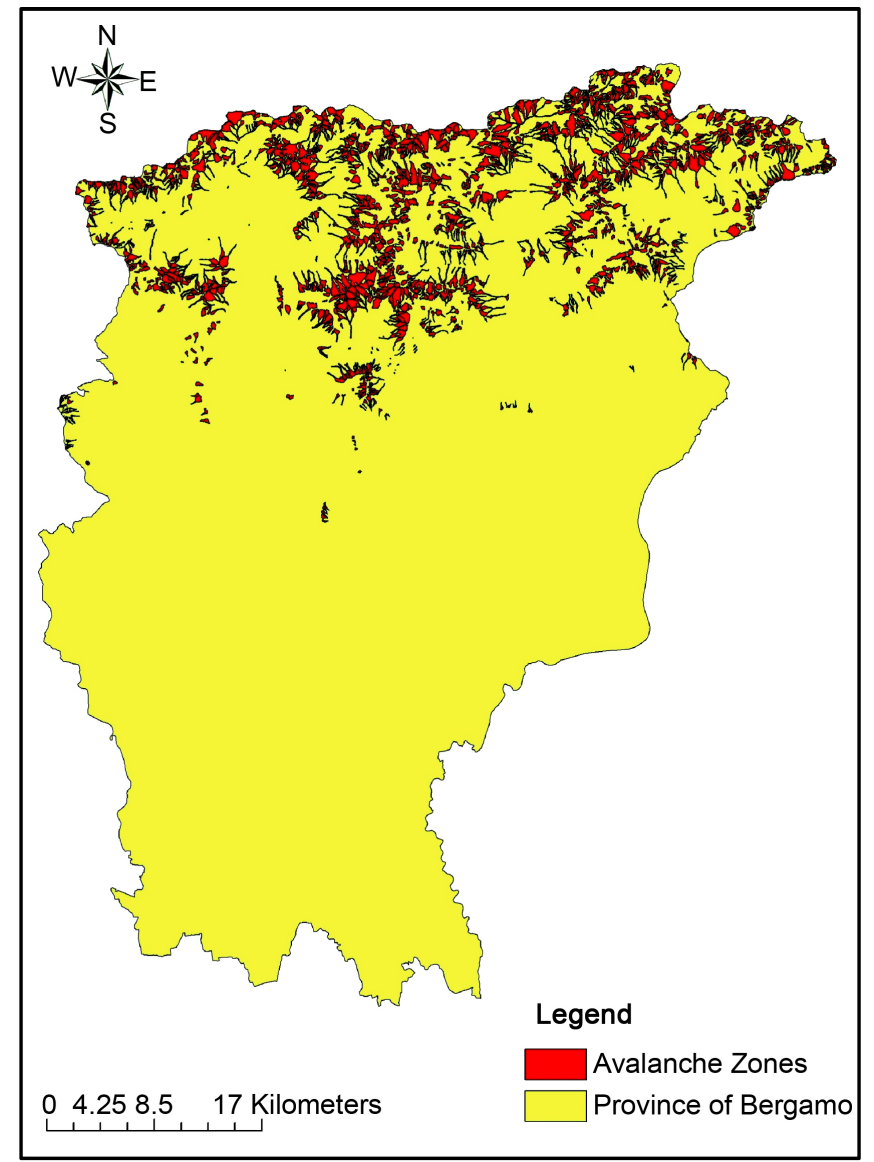

Figure 6. Avalanche zoning in the province of Bergamo.

\section{5,648 Ha.}

The intersecting areas between them are of about 14,253 Ha, which means that the overlapping percentage is $\frac{14253}{20480}=0.6959 \cong 70 \%$ (Figure 8).

The comparison demonstrates that our model provides a wider estimated avalanche zone, if compared to the one of the Province of Bergamo, but also that it doesn't cover some areas at risk.

The difference displayed is certainly due to the simple risk model we adopted, nonetheless the results are quote satisfactory.

\section{Selection of Very High and High Risk Zones}

A following editing step of the raster layer has provided a shapefile with only very high and high risk level areas: Figure 9 illustrates this layer over a raster background of the Province of Bergamo from ArcGIS Imagery Basemap. These areas have a calculated extension of about $8391 \mathrm{Ha}$.

Just these zones are the ones to be monitored with attention and for which a plan of fast and well organized emergency intervention has to be settled.

Afterwards, it has been decided to look for urban areas, ski lifts and power lines existing in these risk areas; for this reason, it has been selected a buffer area of $2 \mathrm{~km}$ around the dangerous zones, taking into account an avalanche descending 


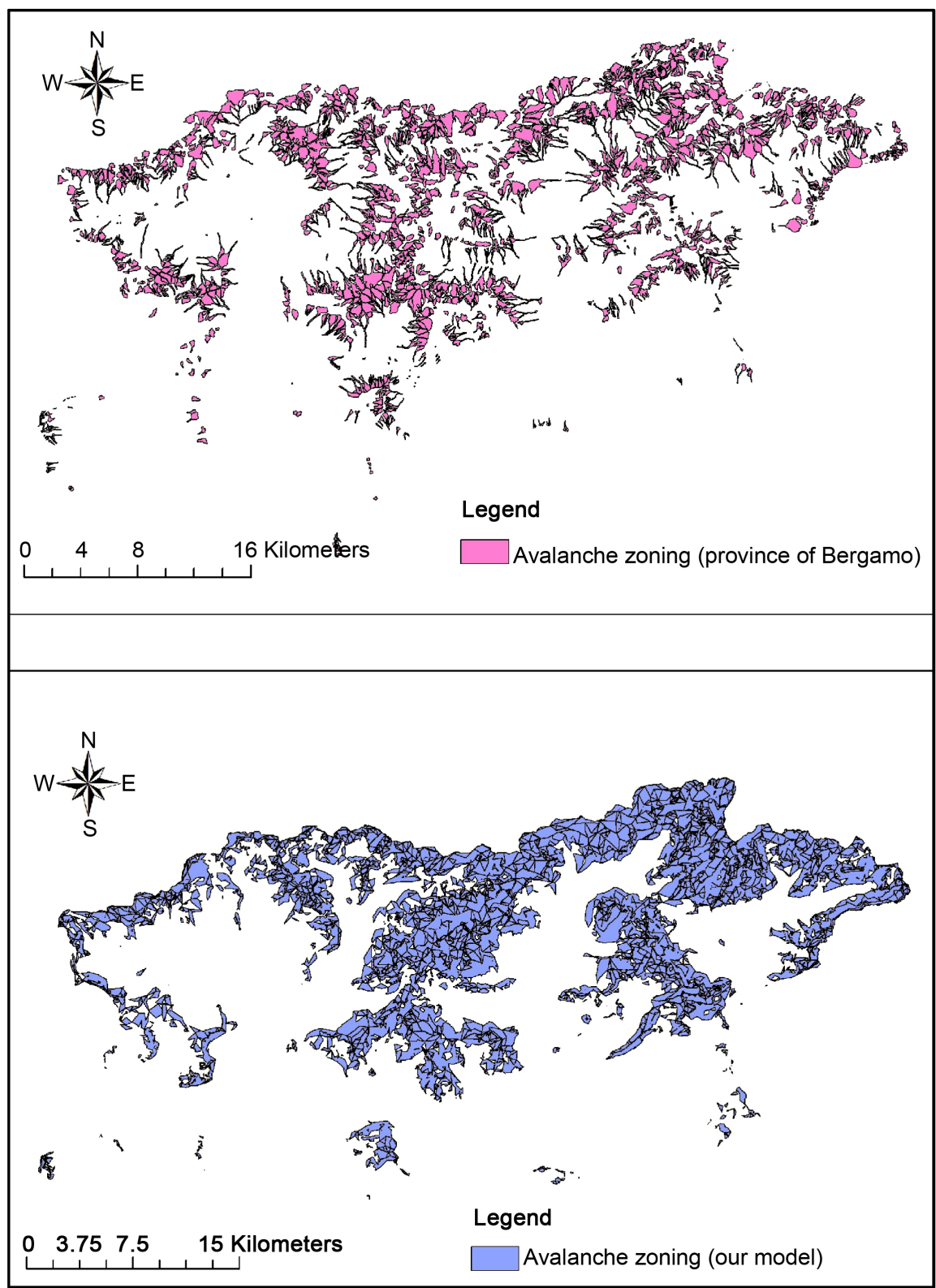

Figure 7. The two avalanche zoning shapefiles: model of the province of Bergamo (top), our model (bottom).

path inside that width. Obviously this is an area far larger than a possible real one, but it's just to get a wide idea.

The three shapefiles have been intersected with the buffer layer and the results have demonstrated that the elements at higher risk are:

- about $284 \mathrm{Ha}$ of urban areas,

- about $27 \mathrm{~km}$ of ski lifts.

- about $45 \mathrm{~km}$ of power lines.

One more important subject has been analysed, with great attention, for its importance to an easy and fast arrival to the damaged areas for allowing emergency intervention: roads and also railroads practicability.

For this reason, the county and town roads, highways and railroad shapefiles 


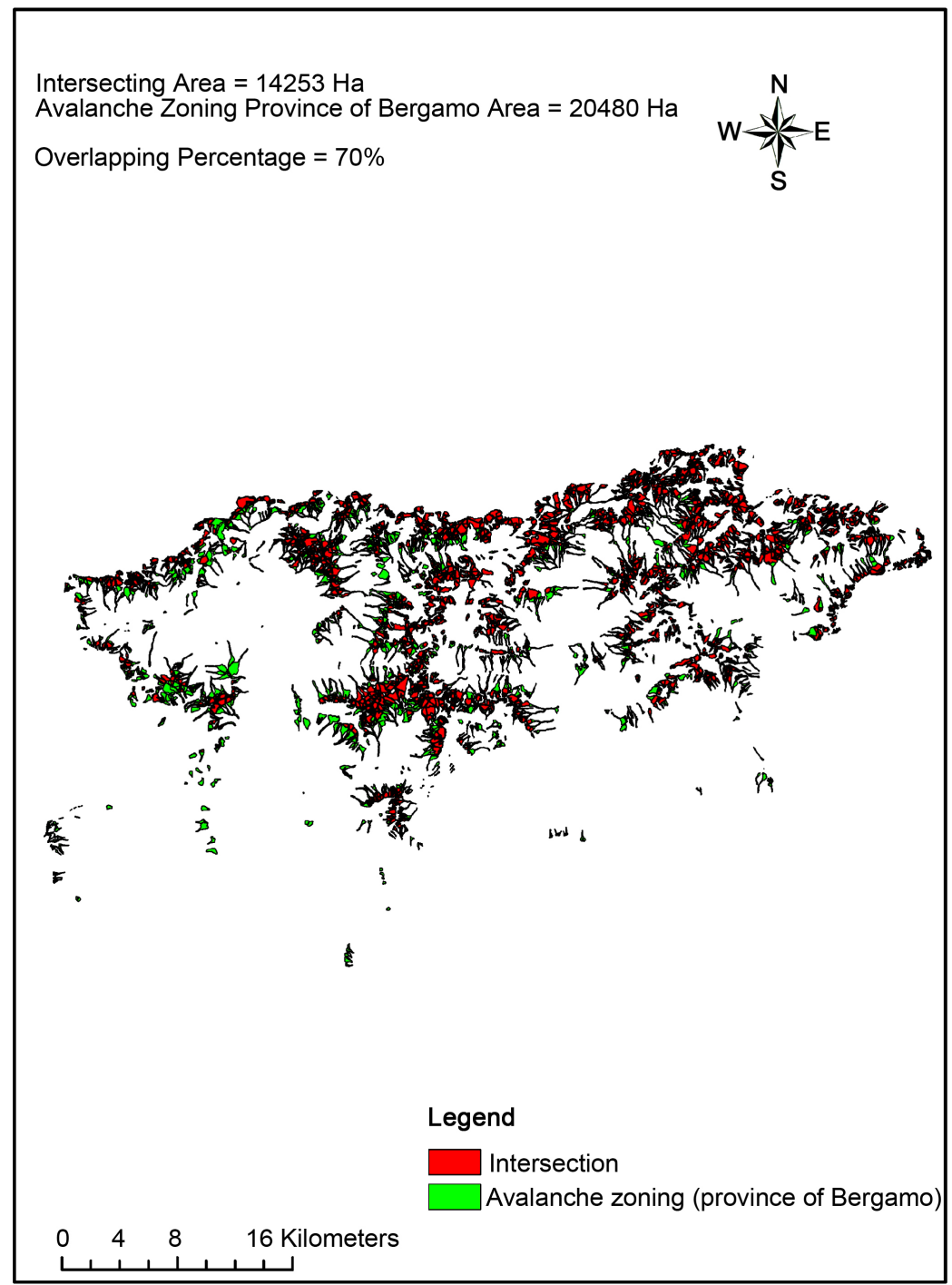

Figure 8. The analytical comparison of the achieved results.

have been downloaded from the Lombardy Geoportal and intersected with the previous dangerous zones with buffers.

The achieved results, of great importance also for future analysis, have provided the following information, pointing out that the elements at risk (highways and railroads result to be safe, since they are very far from these zones) are: - about $60 \mathrm{~km}$ of county roads,

- about $54 \mathrm{~km}$ of town roads.

- All the layers that have been considered for this analysis are described in Figure 10.

\section{Final Remarks and Future Development}

Snow avalanche risk assessment is of high complexity: in this work a highly simplified approach has been adopted, nonetheless providing results in good agreement with the ones used by the Province of Bergamo.

Of course there are pros and cons to consider: our model is faster and easier, 


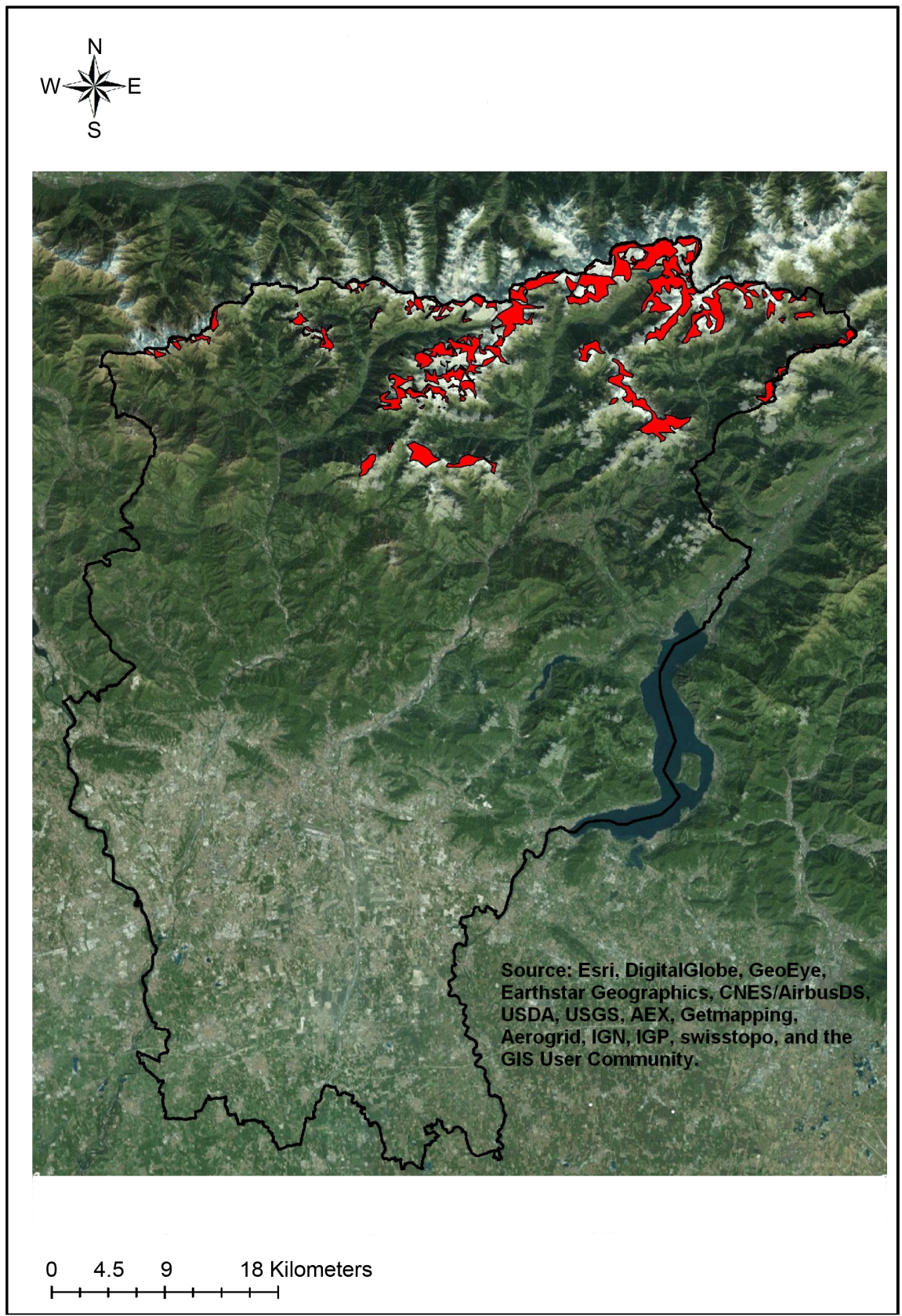

Figure 9. Areas at high or very high avalanche risk.

but it is less accurate and rigorous.

It has already been decided to further develop this analysis and therefore taking into account more specific parameters related to land morphology, geology and to meteorology (i.e. wind, rain and solar radiation), which will provide more accurate results and areas at risk.

These results will then be used to simulate an avalanche casualty happening there and to evaluate the shortest routes and times for ambulances, forest rangers, firemen, police and mountain rescue fastest intervention. Also the hospitals are going to be considered so as to call the nearest ones to prepare emergency wards [39]. 


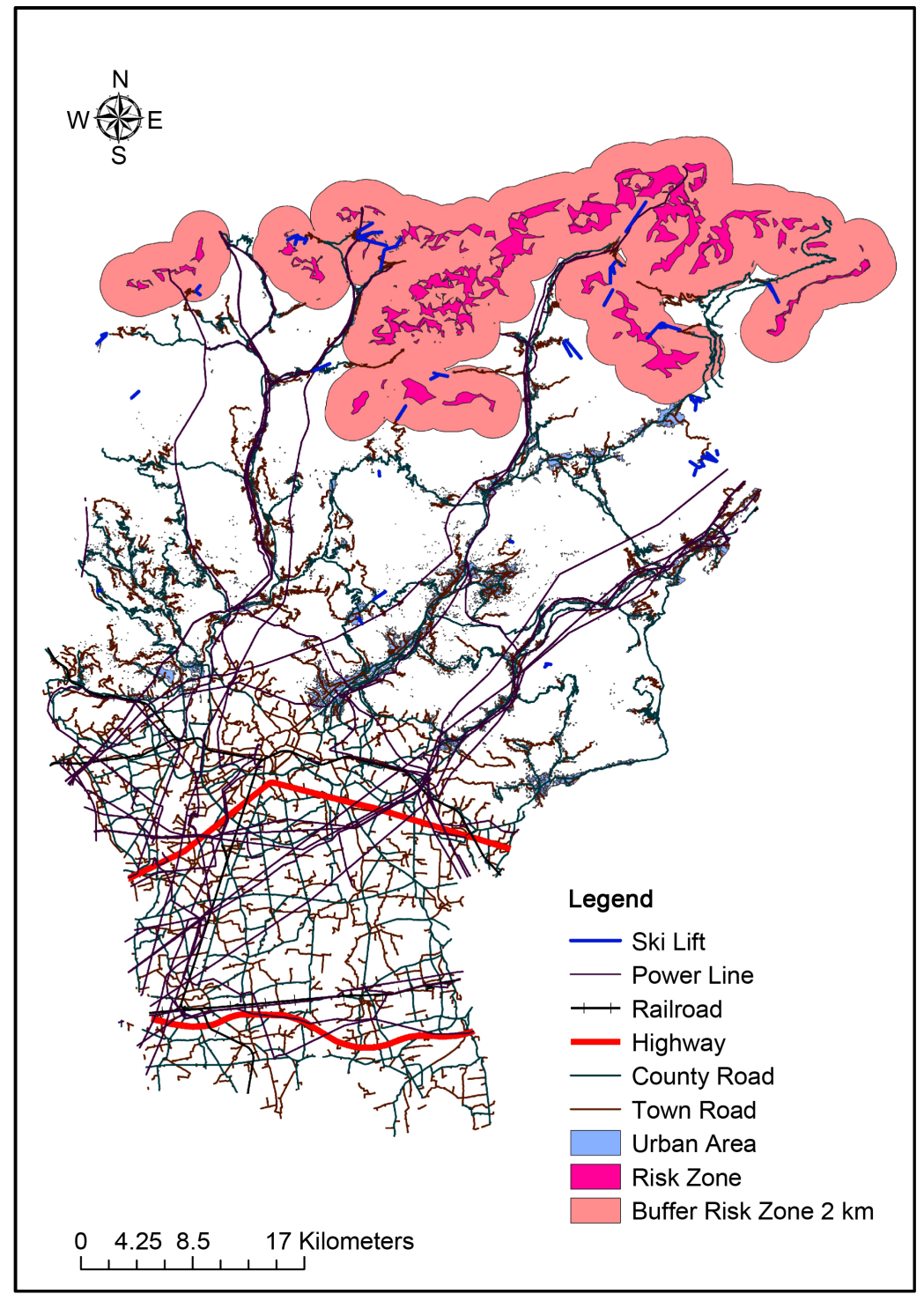

Figure 10. The layers of the final analysis.

Another step could be to develop a geo-app for mobile devices, so as to easily allow everyone to collect fast information about avalanche risk areas.

\section{Acknowledgements}

Thanks for their contribution are due to Professor Luigi Colombo, for his helpful advice, and to our GIS course students at the University of Bergamo (Engineering) Michele Bressanelli and Manuel Rossi.

\section{References}

[1] www.avalanches.org/eaws/en/includes/glossary/glossary_it_all.html

[2] http://www.fondazionemontagnasicura.org/neve-e-valanghe

[3] https://www.theguardian.com/world/gallery/2017/jan/19/avalanche-hotel-abruzzo-i taly-in-pictures

[4] http://www.independent.co.uk/news/world/europe/italy-hotel-rigopiano-abruzzo-a 
valanche-survivors-four-dogs-rescued-reunited-a7539016.html

[5] Keylock, C.J., Mcclung, D.M. and MárMagnússon, M. (1999) Avalanche Risk Mapping by Simulation. Journal of Glaciology, 45, 303-314.

[6] Rousselot, M., Dourand, Y., Giraud, G., Merindol, L. and Daniel, L. (2010) Analysis and Forecast of Extreme New-Snow Avalanches: A Numerical Study of the Avalanche Cycles of February 1999 in France. Journal of Glaciology, 56, 758-770. https://doi.org/10.3189/002214310794457308

[7] Chernouss, P.A. and Fedorenko, Yu. (2001) Application of Statistical Simulation for Avalanche-Risk Evaluation. Annals of Glaciology, 32, 182-186.

[8] Christen, M., Bartel, P. and Kowalski, J. (2010) Back Calculation of the In den Arelen Avalanche with RAMMS: Interpretation of Model Results. Annals of Glaciology, 51, 161-168. https://doi.org/10.3189/172756410791386553

[9] Barbolini, M., Cappabianca, F. and Savi, F. (2004) Risk Assessment in AvalancheProne Areas. Annals of Glaciology, 38, 115-122. https://doi.org/10.3189/172756404781815103

[10] Barbolini, M. and Savi, F. (2001) Estimate of Uncertainties in Avalanche Hazard Mapping. Annals of Glaciology, 32, 299-305. https://doi.org/10.3189/172756401781819373

[11] Cappabianca, F., Barbolini, M. and Natale, L. (2008) Snow Avalanche Risk Assessment and Mapping: A New Method Based on a Combination of Statistical Analysis, Avalanche Dynamics Simulation and Empirically-Based Vulnerability Relations Integrated in a GIS Platform. Cold Regions Science and Technology, 54, 193-205.

[12] http://c.ymcdn.com/sites/www.avalancheassociation.ca/resource/resmgr/Standards Docs/TASARM_English.pdf

[13] Campbell, C., Conger, S., Gould, B., Haegeli, P., Jamieson, B. and Statham, G., Eds. (2016) Technical Aspects of Snow Avalanche Risk Management-Resources and Guidelines for Avalanche Practitioners in Canada. Canadian Avalanche Association, Revelstoke, BC, Canada.

[14] Granger Morgan, M. and Henrion, M. (1990) Uncertainty: A Guide to Dealing with Uncertainty in Quantitative Risk and Policy Analysis. Cambridge University Press, Cambridge, $332 \mathrm{p}$.

[15] http://ramms.slf.ch/ramms/

[16] Christen, M., Kowalski, J. and Bartelt, P. (2010) RAMMS: Numerical Simulation of Dense Snow Avalanches in Three-Dimensional Terrain. Cold Regions Science and Technology, 63, 1-14.

[17] http://www.slf.ch/

[18] http://www.wsl.ch/

[19] Schaerer, P. and McClung, D. (2006) The Avalanche Handbook. 3rd Edition, Mountaineers Books.

[20] Bolognesi, R. (2000) Nivo Test: A Pocket Tool for Avalanche Risk Assessing. Proceedings of International Snow Science Workshop, Big Sky, MT, 554-557.

[21] http://www.provincia.bergamo.it

[22] Nadim, F., Kjekstad, O., Peduzzi, P., Herold, C. and Jaedicke, C. (2006) Global Landslide and Avalanche Hotspots. Landslides, 3, 159-173.

https://doi.org/10.1007/s10346-006-0036-1

[23] Castebrunet, H., Eckert, N., Giraud, G., Durand, Y. and Morin, S. (2014) Projected Changes of Snow Conditions and Avalanche Activity in a Warming Climate: The French Alps over the 2020-2050 and 2070-2100 Periods. The Cryosphere, 8, 1673 - 
1697. https://doi.org/10.5194/tc-8-1673-2014

[24] Voiculescu, M., Ardelean, F., Török-Oance, M. and Milian, N. (2016) Topographical Factors, Meteorological Variables and Human Factors in the Control of the Main Snow Avalanche Events in the FĂGĂRAŞ Massif (Southern CarpathiansRomanian Carpathians): Case Studies. Geographia Polonica, 89, 47-64. https://doi.org/10.7163/gpol.0045

[25] http://www.enchantingitaly.com/regions/lombardia/

[26] www.mountcity.it/index.php/2015/02/24/emergenza-valanghe-sulle-alpi-centro-occ identali-il-73-delle-vittime-secondo-una-valutazione-dellaineva/

[27] www.esri.com

[28] www.geoportale.regione.lombardia.it/

[29] http://atlanteeolico.rse-web.it/

[30] Bründl, M., Bartelt, P., Schweizer, J., Keiler, M. and Glade, T. (2010) Review and Future Challenges in Snow Avalanche Risk Analysis. In: Alcántara-Ayala, I. and Goudie, A.S., Eds., Geomorphological Hazards and Disaster Prevention, Cambridge University Press, Cambridge, 49-62. https://doi.org/10.1017/cbo9780511807527.005

[31] Keylock, C. and Barbolini, M. (2001) Snow Avalanche Impact Pressure-Vulnerability Relations for Use in Risk Assessment. Canadian Geotechnical Journal, 38, 227-238. https://doi.org/10.1139/t00-100

[32] Armstrong, R. and Armstrong, B. (2006) A History of Avalanche Hazard and Avalanche Research in the San Juan Mountains, Southwestern Colorado, USA. Proceedings of the International Snow Science Workshop, Telluride, Colorado, 1-6 October, 298-303.

[33] Fischer, J.T., Kofler, A., Fellin, W., Granig, M. and Kleemayr, K. (2014) Optimization of Computational Snow Avalanche Simulation Tools. Proceedings of the International Snow Science Workshop (ISSW), Banff, Canada, 29 September-3 October 2014, 665-669.

[34] Fischer, J.T., Kofler, A., Fellin, W., Granig, M. and Kleemayr, K. (2015) Multivariate Parameter Optimization for Computational Snow Avalanche Simulation. Journal of Glaciology, 61, 875-888. https://doi.org/10.3189/2015JoG14J168

[35] Eckert, N., Parent, E., Faug, T. and Naaim, M. (2009) Bayesian Optimal Design of an Avalanche Dam Using a Multivariate Numerical Avalanche Model. Stochastic Environmental Research and Risk Assessment, 23, 1123-1141. https://doi.org/10.1007/s00477-008-0287-6

[36] Eckert, N., Parent, E., Kies, R. and Baya, H. (2010) A Spatio-Temporal Modelling Framework for Assessing the Fluctuations of Avalanche Occurrence Resulting from Climate Change: Application to 60 Years of Data in the Northern French Alps. Climatic Change, 101, 515-553. https://doi.org/10.1007/s10584-009-9718-8

[37] Lavigne, A., Eckert, N., Bel, L. and Parent, E. (2015) Adding Expert Contributions to the Spatiotemporal Modelling of Avalanche Activity under Different Climatic Influences. Journal of the Royal Statistical Society: Series C (Applied Statistics), 64, 651-671. https://doi.org/10.1111/rssc.12095

[38] http://mintsnowboarding.com/blog/avalanche-facts-and-tips/

[39] Bründl, M., Etter, H.J., Steiniger, M., Klingler, C., Rhyner, J. and Ammann, W.J. (2004) IFKIS-A Basis for Managing Avalanche Risk in Settlements and on Roads in Switzerland. Natural Hazards and Earth System Sciences, 4, 257-262.

https://doi.org/10.5194/nhess-4-257-2004 
Submit or recommend next manuscript to SCIRP and we will provide best service for you:

Accepting pre-submission inquiries through Email, Facebook, LinkedIn, Twitter, etc. A wide selection of journals (inclusive of 9 subjects, more than 200 journals)

Providing 24-hour high-quality service

User-friendly online submission system

Fair and swift peer-review system

Efficient typesetting and proofreading procedure

Display of the result of downloads and visits, as well as the number of cited articles Maximum dissemination of your research work

Submit your manuscript at: http://papersubmission.scirp.org/

Or contact jgis@scirp.org 